\title{
The Effectiveness Study on CaO Lime Dose and Operation Time Variation and Its Influence on ACID Mine Drainage Treatment
}

\author{
Neny Rochyani, Eddy Ibrahim, M. Faizal, and Ngudiantoro
}

\begin{abstract}
The use of $\mathrm{CaO}$ lime in an effort to neutralized the mine water is common practice in many areas, especially mine coal mines due to the availability of raw materials that are relatively inexpensive and lime in order to raise the $\mathrm{pH}$ capabilities has proven effective. In the mud settling ponds on east Pit 3 West Bangko coal mine, neutralizing the mine water is done by using calcium oxide with a predetermined dose however its has not been measured and analyzed with the appropriate ratio of lime dose that most effective considering operating time to determine the effective activity of lime. This research was conducted to compare various dose of lime and operation time variations in the channel of mud sttling pond so as to provide the information that is most effective conditions for calcification. According to the results of laboratory experiments, it is known that the best $\mathrm{pH}$ is the ratio of lime dose of $0.8 \mathrm{~g} / \mathrm{l}$ to 50 minutes operating time which gained the highest $\mathrm{pH}$ at 7.35. while the results of the measurement of the influence between variables is known that there is a significant relationship between the ratio of lime dose and time of operation to $\mathrm{pH}$ is about $89 \%$ and $93 \%$ and a positive relationship between the increaseoin the ratio of lime dose on $\mathrm{pH}$ and time of operations with the increase of $\mathrm{pH}$.
\end{abstract}

Index Terms-Mine water, the ratio of lime dose, mud settling ponds.

\section{INTRODUCTION}

Coal mining exploitation are generally carried out by using the method of open pit coal mines as well as the West Bangko mine on east Pit 3 that its to open the land surface and excavation pulping (exploration) to get mine material at a certain depth [1]. Such mining activities will have a direct impact to the formation of a reaction between mining materials, air and water so that either directly or indirectly to form acid mine drainage [2].

The formation of acid mine water need to be considered and observed closely because it will greatly affect the environment if not dealt with seriously [3]. This is as a result of the mine water will flow associated with better environmental conditions of land, water or air, which in turn

Manuscript received June 11, 2014; revised August 12, 2014.

Neny Rochyani is with the Department of Environmental Science, Sriwijaya University, Indonesia; she is also with the Department of Chemical Engineering, PGRI Uiversity, Jalan Ahmad Yani Palembang, Indonesia (e-mail: nenyrochyani@yahoo.com).

Eddy Ibrahim is with the Department of Mining Engineering, Faculty of Engineering, Sriwijaya University, Indonesia.

M. Faizal is with the Department of Chemical Engineering, Faculty of Engineering, Sriwijaya University, Indonesia.

Ngudiantoro is with the Department of Mathematic, Faculty of Mathematics and Natural Sciences, Sriwijaya University, Indonesia. will affect the resources used by residents as well as water as a basic requirement [4], [5].

In general, the formation of acid mine water occurs when sulphide minerals contained in the rocks exposed, reacts with water and oxygen. Beside that also the presence of bacteria can accelerate the reaction of acidic water [6]. The reaction of the formation of acid mine drainage is as follows:

$$
4 \mathrm{FeS}_{2}+15 \mathrm{O}_{2}+14 \mathrm{H}_{2} \mathrm{O} \rightarrow 4 \mathrm{Fe}(\mathrm{OH})_{3} \downarrow+8 \mathrm{H}_{2} \mathrm{SO}_{4}
$$

$$
\text { Pyrite + Oxygen }+ \text { Water } \rightarrow \text { "Yellowboy" + Sulfuric Acid }
$$

The reaction between pyrite, oxygen and water forms sulfuric acid and iron hydroxide precipitate. Yellowish color that settles in the bottom of the mine or on the walls of the channel siltation ponds visual representations of the iron hydroxide precipitate (Yellowboy). Reaction In general formation of acid mine water, pyrite occurs in four reactions that produce hydrogen ions when it binds to the ionnegative ions can form acid.

Based on the chemical equation it can be seen the process as follows:

$$
\text { Eq. 1: } \mathrm{FeS}_{2}+7 / 2 \mathrm{O}_{2}+\mathrm{H}_{2} \mathrm{O} \rightarrow \mathrm{Fe}^{+2}+2 \mathrm{SO}_{4}^{-2}+2 \mathrm{H}^{+}
$$

$$
\text { Eq. 2: } \mathrm{Fe}^{+2}+1 / 4 \mathrm{O}_{2}+\mathrm{H}^{+} \rightarrow \mathrm{Fe}^{+3}+1 / 2 \mathrm{H}_{2} \mathrm{O}
$$

$$
\text { Eq. 3: } \mathrm{Fe}^{+3}+3 \mathrm{H}_{2} \mathrm{O} \rightarrow \mathrm{Fe}(\mathrm{OH})+3 \mathrm{H}^{+}
$$

Eq. 4: $\mathrm{FeS}_{2}+14 \mathrm{Fe}^{+3}+8 \mathrm{H}_{2} \mathrm{O} \rightarrow 15 \mathrm{Fe}^{+2}+2 \mathrm{SO}_{4}{ }^{-2}+16 \mathrm{H}^{+}$

Explanation of the above equation:

Equation 1, the iron sulfide is oxidized to release ferrous iron, sulfate and acid. Equation 2, the ferrous iron in the two equations will be oxidized to form ferric iron. Equation 3 , ferric ion can be hydrolyzed to form ferric hydroxide and acid. Equation 4, ferric iron directly react with pyrite and act as a catalyst that causes a very large ferrous iron, sulfate and acid [7].

For handling that situation. It has been done by concentrating the water formed into a sump that its on front mine has been fitted with a pump that is used to drain the water that already exists. To achieve channel on the surface of the pipe used to connect to the existing pump. Pumping activities carried out by a certain period and then the water will be pumped to the siltation of canals and ponds.

Based on the preliminary data obtained by measuring the quality of water that accumulates in the settling pond mud pit 3 east Bangko West obtained a low $\mathrm{pH}$ value $(\mathrm{pH} \pm 3)$, the low $\mathrm{pH}$ value was still below of the value of environmental quality standards. To mitigate liming with 
calcium oxide $(\mathrm{CaO})$, calcium oxide administration carried on mud settling ponds at the inlet.

The mine water management activities in the pool precipitator Mud PIT 3 East on West Banko mine using active methods by performing calcification directly into a body of water in the sludge settling ponds. The method used was quite effective, but calcification was done needs to be studied further mainly concerning the ratio of lime dose and the most appropriate time to do the surgery so that it can be seen that most good dose of lime and operating time as well as the addition of lime at the end of time that should be done. This research emphasis on the problems of the dose ratio of lime to mine water management activities and operating in the best time, so that can know the dose ratio of the effective use of lime mud settling ponds mine in West Bangko PIT 3 East. On the other hand also discuss the influence of lime dose and time of operation of the increase in $\mathrm{pH}$.

Based on the issues to be discussed, the purpose of this study was to determine the dose ratio of lime to raise the $\mathrm{pH}$ of the most good in the laboratory tests, knowing the ratio of lime dose on a laboratory scale and field application, determine the amount of lime requirement in accordance with the results of measurements and determine the effect caused by lime dose and time of operation of the increase in the $\mathrm{pH}$ of the water. While the expected benefits of this research in order to know the method and the ratio of lime dose is effective and efficient which can be adopted by companies for the environmental management of mining.

\section{METHOD}

\section{A. Laboratory Studies}

To determine the ratio of lime dose with time variations in laboratory experiments conducted using a sample of mine water settling ponds sludge to reach the limits of environmental quality standards.

Research variables:

1) mine water samples

2) lime dose $(0.5 \mathrm{~g} / 1,0.6 \mathrm{~g} / \mathrm{l}, 0.7 \mathrm{~g} / \mathrm{l}, 0.8 \mathrm{~g} / \mathrm{l}, 0.9 \mathrm{~g} / \mathrm{l}$ and 1 $\mathrm{g} / \mathrm{l})$

3) operating time (30, 40 and 50 minutes)

\section{B. The Effect of Lime Dose Ratio and Operation Time on the $\mathrm{pH}$ of the Water}

The measurement of the effect of dose ratio of lime toincrease $\mathrm{pH}$ is done to determine the influence of the independent variable (the ratio of lime dose) against $\mathrm{pH}$ (dependent varabel) [8]. Besides, it also can be seen the correlation (relationship) between variables whether negative or positive. To perform the measurements by using simple regression method.

The Pearson Product Moment Correlation formula (PPM):

$$
r_{x y}=\frac{N \Sigma x y-\left(\sum x\right)\left(\sum y\right)}{\sqrt{\left(N \Sigma x^{2}-\left(\sum x\right)^{2}\left(N \Sigma y^{2}-(\Sigma y)^{2}\right)\right.}}
$$

Description:

count $r=$ coefficient correlation
$X=$ independent variable

$Y=$ dependent variable

$N=$ Number of respondents

Correlation analysis will look the degree of the relationship and the direction of the relationship. Correlation values are in the range of 0 to 1 or 0 to -1 . Positive and negative sign indicates the direction of the relationship. Positive sign indicates the direction of change is the same. If one variable goes up, the other variable also rose, while a negative sign indicates a change in the opposite direction. If one variable goes up, the other variables are actually down. If the value of $r=-1$ means a perfect negative correlation: $r$ $=0$ means no correlation, and $r=+1$ means that the correlation is very strong [9].

\section{RESUlTS AND DISCUSSION}

\section{A. The Ratio of Lime Dose and Time of Laboratory Scale Operations}

The laboratory experiment aims to determine the appropriate ratio of lime dose to raise the $\mathrm{pH}$ of acid mine water from the pool precipitator Mud Pit 3 West Bangko East with the most effective time variation. From this laboratory experiment data showed lime changes the $\mathrm{pH}$ of the dose (Table I), where dose of lime to raise the $\mathrm{pH}$ of acid mine water in the pool precipitator Mud Pit west Bangko East with initial pH $3 \pm 3$ (Table) until the water comes out in accordance with the Environmental Quality Standard ( $\mathrm{pH}$ 6-9) [10], [11] are limestone with a dose of $0.8 \mathrm{~g} /$ liter. As for the variation of the operating time can be seen that the most effective operating time was 50 minutes at a time where the operation showed the highest $\mathrm{pH}$ of 7.35. This is due to a longer stirring time, so the solution becomes more homogeneous and the settling time is relatively longer and will cause the concentration of absorption solution for the better and will ultimately raise the $\mathrm{pH}$ of the water.

The laboratory experiment result for 50 minutes operating time condition as in the following Table I.

TABLE I: LABORATORY TEST RESULT
TIME: 30 MinUTES
\begin{tabular}{|l|l|l|l|l|l|l|}
\hline \multirow{2}{*}{ Trial } & $\mathrm{pH}$ on Dose & & \\
\cline { 2 - 7 } & $0.5 \mathrm{~g} / 1$ & $0.6 \mathrm{~g} / 1$ & $0.7 \mathrm{~g} / 1$ & $0.8 \mathrm{~g} / 1$ & $0.9 \mathrm{~g} / 1$ & $1.0 \mathrm{~g} / 1$ \\
\hline 1 & $4: 20$ & 4.91 & $6: 02$ & $7: 13$ & $8: 46$ & $9: 21$ \\
\hline 2 & $4: 23$ & 4.93 & 5.99 & $7: 15$ & $8: 44$ & $9: 20$ \\
\hline 3 & $4: 24$ & 4.92 & $6: 01$ & $7: 14$ & $8: 47$ & $9: 18$ \\
\hline 4 & $4: 25$ & 4.93 & 5.99 & $7: 14$ & $8: 45$ & $9: 19$ \\
\hline 5 & $4: 24$ & 4.94 & $6: 02$ & $7: 16$ & $8: 45$ & $9: 20$ \\
\hline Number & & & & & & \\
\hline Average & $4: 23$ & 4.92 & $6: 01$ & $7: 14$ & $8: 45$ & $9: 19$ \\
\hline
\end{tabular}

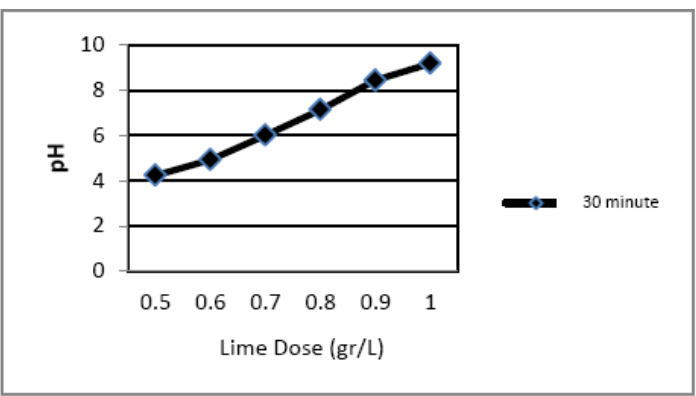

Fig. 1. Results of laboratory tests for the operating time of 30 minutes. 
The explaination about data above by using graph as shown with Fig. 1.

Then the results of the experiment for 40 minutes operating time as there in the following Table II.

TABLE II: LABORATORY TEST RESULT TIME: 40 MINUTES

\begin{tabular}{|l|l|l|l|l|l|l|}
\hline \multirow{2}{*}{ Trial } & \multicolumn{6}{|l|}{$\mathrm{pH}$ on Dose } \\
\cline { 2 - 7 } & $0.5 \mathrm{~g} / 1$ & $0.6 \mathrm{~g} / 1$ & $0.7 \mathrm{~g} / 1$ & $0.8 \mathrm{~g} / 1$ & $0.9 \mathrm{~g} / 1$ & $1.0 \mathrm{~g} / 1$ \\
\hline 1 & $4: 25$ & $5: 00$ & $6: 10$ & $7: 18$ & 8.60 & $9: 30$ \\
\hline 2 & $4: 26$ & $5: 10$ & $6: 06$ & $7: 20$ & 8.65 & $9: 32$ \\
\hline 3 & $4: 27$ & $5: 12$ & $6: 15$ & $7: 21$ & 8.69 & $9: 35$ \\
\hline 4 & $4: 25$ & $5: 13$ & $6: 01$ & $7: 25$ & 8.69 & $9: 36$ \\
\hline 5 & $4: 27$ & $5: 15$ & $6: 15$ & $7: 28$ & 8.70 & $9: 40$ \\
\hline Number & & & & & & \\
\hline Average & $4: 26$ & 5.1 & $6: 09$ & $7: 22$ & 8.67 & $9: 35$ \\
\hline
\end{tabular}

The explaination about data above by using graph as shown with following Fig. 2.

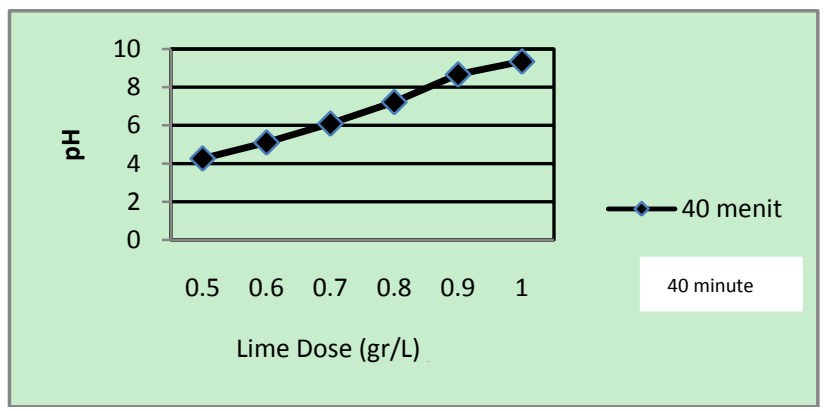

Fig. 2. Results of Laboratory Tests for the operating time of 40 minutes.

Finally the results of the experiment for 30 minutes operating time as there in the following Table III.

TABLE III: LABORATORY TEST RESULT TIME: 50 MINUTES

\begin{tabular}{|l|l|l|l|l|l|l|}
\hline \multirow{2}{*}{ Trial } & \multicolumn{1}{|l}{ pH on Dose } & \multicolumn{5}{l|}{$\mid$} \\
\cline { 2 - 7 } & $0.5 \mathrm{~g} / 1$ & $0.6 \mathrm{~g} / 1$ & $0.7 \mathrm{~g} / 1$ & $0.8 \mathrm{~g} / 1$ & $0.9 \mathrm{~g} / 1$ & $1.0 \mathrm{~g} / 1$ \\
\hline 1 & $4: 30$ & $5: 22$ & $6: 25$ & 7.30 & 8.90 & 9.53 \\
\hline 2 & $4: 36$ & $5: 25$ & $6: 23$ & 7.31 & 8.78 & 9.55 \\
\hline 3 & $4: 35$ & $5: 25$ & $6: 30$ & 7.35 th & 8.98 & 9.57 \\
\hline 4 & $4: 40$ & $5: 29$ & $6: 35$ & 7.35 th & 8.99 & 9.66 \\
\hline 5 & $4: 35$ & $5: 28$ & $6: 35$ & 7.30 & 8.90 & 9.65 \\
\hline Number & & & & & & \\
\hline Average & $4: 35$ & $5: 26$ & 6.3 & $7: 32$ & 8.91 & $9: 59$ \\
\hline
\end{tabular}

The explaination about data above by using graph is shown with following Fig. 3.

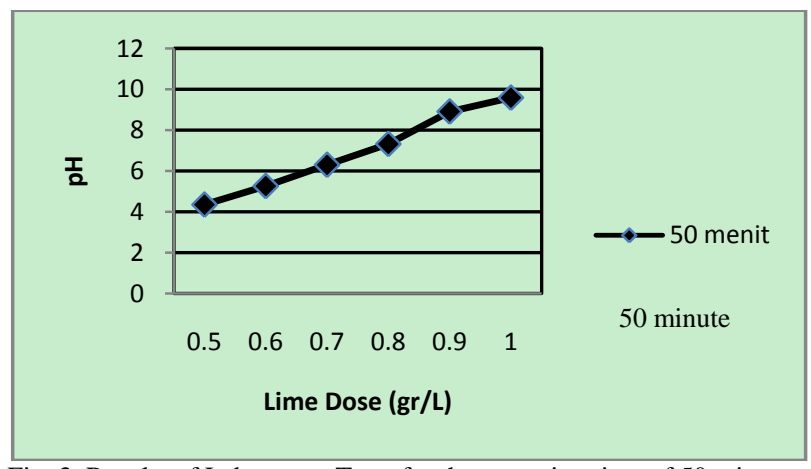

Fig. 3. Results of Laboratory Tests for the operating time of 50 minutes.
To compare the result for each operation time condition as there in the following Fig. 4.

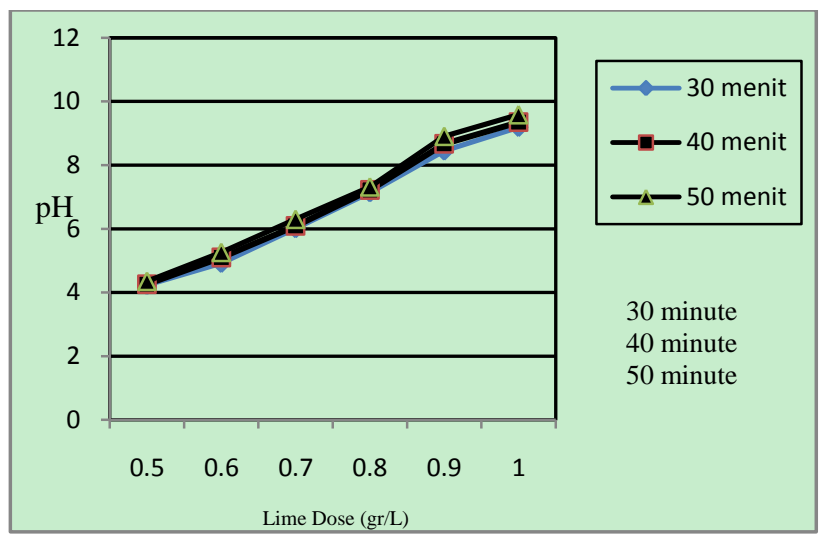

Fig. 4. Comparison chart of lime dose ratio with variation of operating time.

According on preliminary experiments on the $\mathrm{pH}$ of the mine water that was obtained on the following Table IV.

TABLE IV: PH SAMPLE ON EAST PIT 3 WEST BANGKO
\begin{tabular}{|l|l|l|}
\hline No. & Time & $\mathbf{p H}$ \\
\hline 1. & 14 April 2013 & 3,65 \\
\hline 2. & 15 April 2013 & 3.22 \\
\hline 3. & 16 April 2013 & 3.26 \\
\hline 4. & 18 April 2013 & 3,33 \\
\hline 5. & 21 April 2013 & 3.77 \\
\hline
\end{tabular}

The tools used to measure $\mathrm{pH}$ in this study was Testr $\mathrm{pH}$ 30 .

\section{B. Water Debit Calculation}

The source of water that goes into the Mud Setling Pondon East Pit 3 West Bangko was derived from the main sump of the mining front that was pumped to the top and then channeled through culverts with a diameter of 1 meter.

Based on the data output from the water pipes, it is known:

$$
\begin{aligned}
\mathrm{Q} & =0.2433 \mathrm{~m}^{3} / \mathrm{s} \times 3600 \mathrm{~s} / \mathrm{hr} \times 1000 \mathrm{dm}^{3} / \mathrm{m}^{3} \\
& =875880 \mathrm{dm}^{3} / \text { hour }
\end{aligned}
$$

$$
\mathrm{Q}=875880 \text { liters / hour }
$$

\section{Lime Requirement Calculation}

Based on the test results obtained in the laboratory and measuring the ratio of effective dose of lime to raise the $\mathrm{pH}$ of acid mine water in the pool precipitator Mud Pit 3 West Bangko East to achieve environmental quality standards that limit the dose of 0.8 grams / liter. And the results of calculation of the amount of water flow that enters the western Bangko mud settling precipitator East Pit 3 in the amount of 875880 liters/hour, so it can be expected that the use of lime:

The amount of lime dose $\times \mathrm{Q}=$ total $=0.8$ grams $/$ liter $\times 875880$ liters $/$ hour $=770704 \mathrm{~g} /$ hour $=770.704 \mathrm{~kg} /$ hour 
Weight $1 \mathrm{bag}=40 \mathrm{~kg}$

The amount of lime per hour $=$ 19.26 bags / hour $\approx 19$ sacks / hour

The amount of use of lime is $770.704 \mathrm{~kg} /$ hour or about 19 bags / hour for an intake capacity of 875880 liters / hour, assuming a weight of $1 \mathrm{bag}=40 \mathrm{kgs}$. The analysis was limited to theory, it is necessary to be done directly in the field experiments to prove the above calculation.

\section{The Effect of Lime Doses on Increasing of $\mathrm{pH}$}

The main goal of this treatment is to determine the optimum conditions at a dose of lime to raise the $\mathrm{pH}$ and to achieve environmental quality standards is between 6 and 9 . With such a reference would be effective for the management of mine water in the mine produced. While the variation in the time spent was 30 minutes, 40 minutes and 50 minutes. With such circumstances it can be seen that the optimum conditions of $\mathrm{pH} 3.2$ using the original lime can effectively raise the $\mathrm{pH}$ is equal to 7,8 at a dose of lime 0.8 $\mathrm{g} / 1$ to 50 minutes operating time. This is compared with another dose of lime can be seen that the tendency of highdose semaikin dibeikan lime will result in the higher $\mathrm{pH}$. To find a significant effect of dose of lime to $\mathrm{pH}$ then subsequently measured using a statistical approach, and it is known that on average $89 \%$ increase in the $\mathrm{pH}$ is influenced by the dose of lime ratio. When viewed from the regression coefficient and the regression curve exists, it can be said that there is a positive relationship between increasing doses of lime with increasing on mine water $\mathrm{pH}$. It can be concluded that the higher on lime dose the higher increasing on $\mathrm{pH}$.

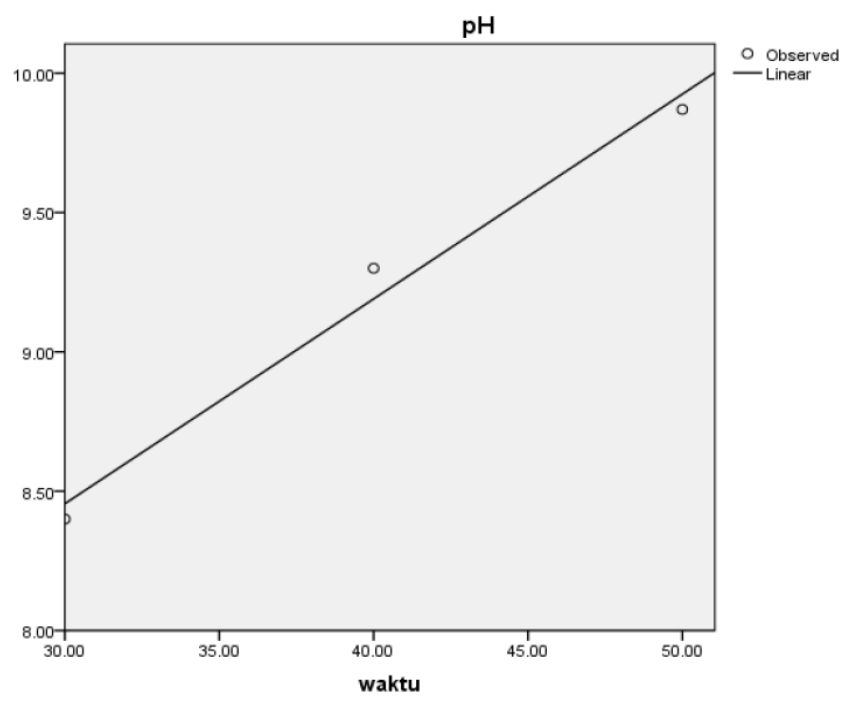

Operation Time

Fig. 5. The effect of lime dose on increasing $\mathrm{pH}$.

From the experiments result that conducted to determine the dose of calcification can be seen that in the past of optimum conditions, the addition of lime could make more alkaline on water which reducing existing water quality. It may therefore be concluded that addition of lime will raise on the $\mathrm{pH}$ but it still need to be considered a safe dose in calcification.

Statistic measurement for determine the effect of lime dose on $\mathrm{pH}$ of mine water as in following Table $\mathrm{V}$.
TABLE V: THE EFFECT OF LIME DOSE ON INCREASING PH

\begin{tabular}{|l|l|l|l|l|l|}
\hline \multicolumn{6}{|l|}{ Model Summary } \\
\hline Model & $\mathrm{R}$ & R Square & $\begin{array}{l}\text { Adjusted } \\
\text { Square }\end{array}$ & $\begin{array}{l}\text { Std.Error of the } \\
\text { Estimate }\end{array}$ \\
\hline 1 & $.945^{\mathrm{A}}$ & .893 & .786 & .26944 \\
\hline
\end{tabular}

The tends of relationship between lime dose and $\mathrm{pH}$ as shown with Fig. 5.

\section{E. Effect of Operating Time against the Increasing on $\mathrm{pH}$}

From the measurement of $\mathrm{pH}$ mine water through the process of calcification by using a jar test and a $\mathrm{pH}$ meter, can be seen that the operating time has significant impact on the average reached $93 \%$ at each dose calcification. It can be concluded that the longer the operating time will be done anyway steeper increase in the $\mathrm{pH}$ of the mine water. This can happen because the longer the mixing process which will lead to honmogenitas water, the better to absorb the subsequent settling time is also relatively similar with stirring time that make a better concentration and increase on $\mathrm{pH}$ will be higher.

Statistic measurement for determine the effect of operation time on $\mathrm{pH}$ of mine water as in following Table VI.

TABLE IV: EFFECT OF OPERATION TIME ON THE PH MODEL SUMMARY

\begin{tabular}{|l|l|l|l|l|}
\hline Model & $\mathrm{R}$ & $\begin{array}{l}\mathrm{R} \\
\text { Square }\end{array}$ & $\begin{array}{l}\text { Adjusted } \\
\text { Square }\end{array}$ & $\begin{array}{l}\text { Std.Error of the } \\
\text { Estimate }\end{array}$ \\
\hline 1 & $.964^{\mathrm{A}}$ & .929 & .858 & .22454 \\
\hline
\end{tabular}

The tends of relationsh if between operation time and $\mathrm{pH}$ as shown with following Fig. 6 .

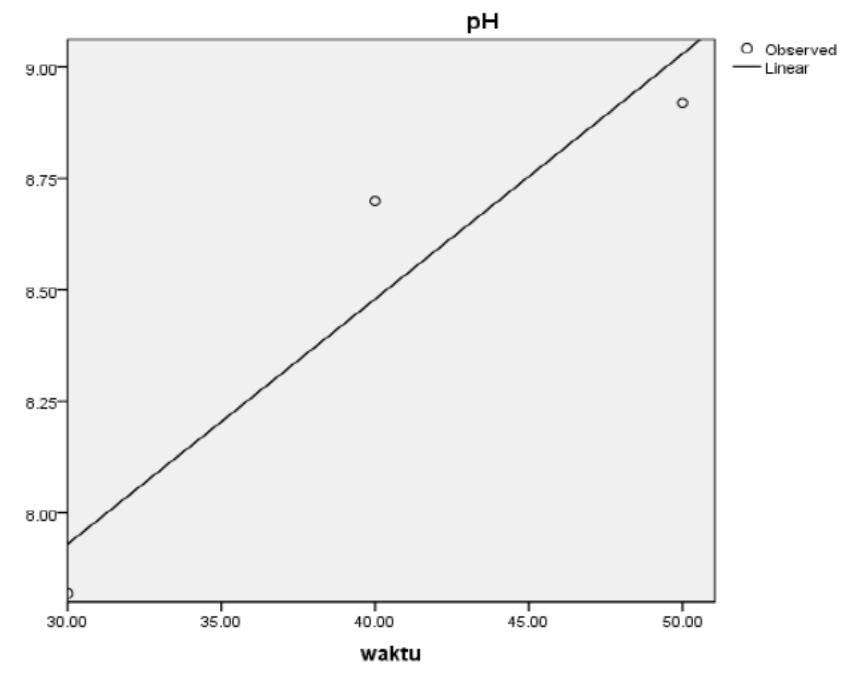

Operation Time

Fig. 6. The effect of operating time on increasing $\mathrm{pH}$.

\section{CONCLUSIONS AND RECOMMENDATIONS}

\section{A. Conclusion}

From the foregoing discussion, it can be drawn some conclusions, namely:

1) From laboratory scale experiments lime doses can raise the $\mathrm{pH}$ of acid mine water from the mud settling ponds of West Bangko Pit $3 \pm \mathrm{pH} 3$ to reach the minimum environmental quality standards was lime with lime 
dose ratio $0.8 \mathrm{~g} / \mathrm{L}$, with 50 minutes of operation time.

2) Comparison of operating time for the best dose is $0.8 \mathrm{~g} /$ liter was brackish respectively 7,15 for 30 minutes, 7.28 for 40-minute operation time and operation time of 7.35 for 50 minutes. It can be concluded that a longer operating time effect on better incrase of $\mathrm{pH}$.

3) Based on laboratory results are known the needs of lime per hour was $770.704 \mathrm{~kg}$ (19 sacks).

4) Statistical test results showed that a significant difference between the dose of lime with increasing $\mathrm{pH}$ and showed a positive meaning, increasing doses of lime will raise the $\mathrm{pH}$.

5) Statistical test results showed that a significant difference between the time of surgery with increasing $\mathrm{pH}$ and showed a positive meaning, the increase in operating time will increase the $\mathrm{pH}$ anyway.

\section{B. Suggestion}

Based on the observations that have been made in the field, then there are some suggestions that can give Authors include:

1) If calcification using active methods of lime should be done with the right amount on line Mud settling pond swift and the currents will always stir the lime so that the lime precipitation can be minimized and the use of lime can be more efficient.

2. In order to maximize the results of calcification should be stirring the mud settling ponds that really quicklime reacts with acidic water that is at the pool.

\section{ACKNOWLEDGEMENTS}

This work was made possible through a permission from management of PT. bukit asam, the coal mine that give us an opportunity to research and work in coal mine field at west banko. And special thanks to all of employee on coal mine field that support and helping us providing every equipment that we all needs.

\section{REFERENCES}

[1] H. L. Hartman, Introductory Mining Engineering, New York, John Wiley and Sons Inc, 1987.

[2] T. Hidir, "Characteristics of acid mine water in mine environmental PIT 1 banko west, Tanjung Enim in South Sumatra," Journal of Environmental Engineering, Jakarta, vol. 9, no. 3, pp. 54-62, 2008.

[3] E. Widyati, AMD - Specter Land Mine Used, Jakarta, pp. 70-77, 2008.

[4] I. Eddy, "Environmental degradation due to mining," in Proc. the National Seminar on Environment Handling After Mine, Palembang October 2009, UNSRI Research Institute.

[5] J. Fripp et al., "Acid mine drainage treatment," Journal EMRRP ERDC-TN-SR-14, Baltimore, USA, 2000.

[6] J. P. Widdowson and M. Ali, "Utilization of biological resources local for passive control of acid mine water," Journal of Soil and Environmental Science, vol. 7, no. 1, 2007.

[7] J. Skousen and A. Rose, A Handbook of Technologies for Avoidance and Remediation of Acid Mine Drainage, the National Mine Land Reclamation Center Located at West Virginia University in Morgantown, West Virginia, 1998

[8] Riduwan, The Introduction of Statistic, Bandung: Alfa Beta, 2008.

[9] I. Eddy, W. D. H. Endang, and D. Fendianza, "Evaluate the effectiveness of calcification between the inlet and outlet channel in the handling of acid mine at settling ponds sludge," Journal IATPI, pp. 43-50, 2010
[10] Technical Guidelines for Management of Coal Mine Wastewater, the Ministry of Environment, 2008.

[11] Water Quality and Water Pollution Control, Government Regulation no. $82,2001$.

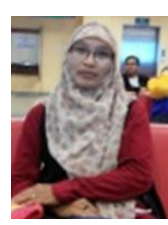

Neny Rochyani was born in Palembang on June 9, 1970 Curently she is a lecturer at PGRI University Palembang, Indonesia and active as a promoter for students on many researches. She has graduated from formal education on chemical engineering at Sriwijaya University in 1996.

She had completed a master's degree on program in industrial technology at Sriwijaya University in 2001 and now she is a doctoral candidate in the same university. She is currently also active in the field of environment and energy researches. She has already published many journals and researches.

Ms. Neny Rochyani was active on many association and science institution such as MASTAN. In this research she acts as a researcher and an author.

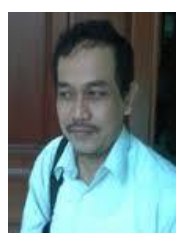

Eddy Ibrahim was born in Pangkal Pinang, Indonesia in 1962. Currently he is working as a lecturer in the Department of Mining Engineering, Faculty of Engineering and as a chief of Graduate School Program on environment science in University of Sriwijaya. He has completed formal education engineering degree in the Department of Mining Engineering, Faculty of Engineering, Sriwijaya University in 1987.

He has completed a master's program at ITB in 1998 and a doctora program in the same university in 2010 . He is currently also active in the field of environment and energy researches. He has already published many journals and researches.

Prof. Eddy ibrahim was active on many association and science institution such as HAGI, PERHAPI, etc. In this research he act as a promotor and an author.

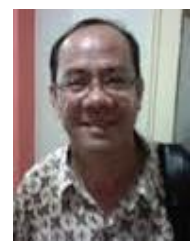

Muhammad Faizal was born in Palembang Indonesia on May 14, 1958. Currently he is working as a lecturer in the Department of Chemical Engineering, Faculty of Engineering and at Graduate School Program (master and doctor program), University of Sriwijaya. He has completed formal education engineering degree in the Department of Chemical Engineering Faculty of Engineering, Sriwijaya University in 1983

He has completed a master's program in ENSCT-INPT Toulouse France in 1988, and a doctoral program in the same university in 1991 . He is currently also active in the field of environment and energy researches. His several scientific publications have been published: The $8^{\text {th }}$ Biomass Asia Workshop at Hanoi (Vietnam) in 2011, The First Middle East Drying in Iran 2012, International Journal of Biological, Ecological and Environmental Science (IJBEES) vo. 2 no. 1, 2012; The 2012 International Conference on Sustainable Environmental Technology (ICSET) at Bangkok-Thailand, Sustainable Research, vol. 22, no. 6, pp. 395-400, 2012, The $1^{\text {st }}$ International Conference on Current Issues in Education (ICCIE 2012), Yogyakarta, 2012 Indonesia, International Seminar $1^{\text {st }}$ Fisheries and marine Industralization, Pekanbaru, Indonesia, The $3^{\text {rd }}$ International Conference on Latest Trend in Engineering \& Technology (ICLTET 2013) and The $3^{\text {rd }}$ Conference on Economics, Humanities, Bio-Technology and Environment Engineering (ICEHBEE 2013), Bali Indonesia,

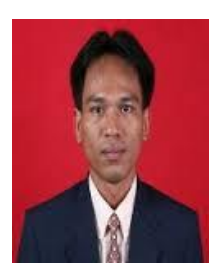

Ngudiantoro was born in Blitar, on October 10, 1971 Currently he is working as a lecturer in the Department of Mathematic and Science Faculty and as a lecturer on Graduate School Program on environment science in University of Sriwijaya. He has completed formal education science degree in the Department of Mathematic Faculty of mathematic and science, Sriwijaya University in 1996

$\mathrm{He}$ has completed a master's program in statistic at IPB, Bandung in 2004 and a doctoral program in the same university in 2009. He is currently also active in the field of environment and energy researches. And already publish many jounal and researches.

Dr. Ngudiantoro acts as a promotor and an author in this research. 